\author{
(1) Müjde Çalıkuşu İncekar, \\ (D) Eda Çeçen, \\ (1) Serap Balcı, \\ (D) Birsen Mutlu, \\ (1) Nehir Ulu Öğüt, \\ (D) Şahin Hamilçıkan
}

Received/Geliş Tarihi : 27.06.2018

Accepted/Kabul Tarihi : 12.09.2018

${ }^{\circ}$ Copyright 2019 by Turkish Society of Intensive Care Turkish Journal of Intensive Care published by Galenos Publishing House.

Müjde Calıkuşu Incekar,

Istanbul Gedik University Faculty of Health Sciences,

Department of Nursing, Istanbul, Turkey

Serap Balcı, Birsen Mutlu

Istanbul University, Faculty of Florence Nightingale

Nursing, Istanbul, Turkey

Eda Çeçen, Nehir Ulu Öğüt, Şahin Hamilçıkan University of Health Sciences Bagcilar Training and Research Hospital, Neonatal Intensive Care Unit, Istanbul, Turkey

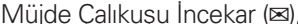

Istanbul Gedik University Faculty of Health Sciences, Department of Nursing, Istanbul, Turkey

E-mail : mujdecalikusu@gmail.com

Phone : 4445438-1230

ORCID ID : orcid.org/0000-0002-4472-2406

\section{The Effect of Education in Reducing Noise on Health Personnels' Knowledge Level and Behavioral Change}

\author{
Gürültünün Azaltılmasında Çalışanlara Verilen Eğitimin \\ Bilgi Düzeyi ve Davranış Değişikliği Üzerine Etkisi
}

ABSTRACT Objective: Noise must be reduced and taken under control because negatively affects the health of health personnel and preterm newborns in particular. The American Academy of Pediatrics reported that noise levels must be kept below $45 \mathrm{~dB}$. However, many studies demonstrated that the desired level could not be reached. This research was conducted with the aim of evaluating the level of noise in a neonatal intensive care unit (NICU), and the effect of given education on controlling the noise.

Materials and Methods: This research was conducted with doctors (4), nurses (18), and personnel (4) who worked in the $3^{\text {rd }}$ level NICU of a university hospital. This research had a pre-test, post-test quasi-experimental design in a single group. Ethics board and institutional approval were granted from the hospital. A noise information form that was prepared by researchers, educational program on noise control, noise observation form, and noise measuring equipment were used in the study. Noise was measured for 24 hours over 7 days in repeated measurements in the unit before education, after education, and 6 weeks after the education program.

Results: The noise levels were significantly lower 6 weeks after the education program compared with before the program $(p<0.01)$. The percentage of correct answers given to questions in the information form was significantly higher 6 weeks after the education program compared with before the program among health personnel $(p<0.01)$. The kappa compliance level was found significant among observers in the evaluation of doctors, nurses, and personnel in accordance with the noise observation form $(p<0.01)$.

Conclusion: It could be suggested that the education method was effective in terms of reducing noise, reducing noise levels in the environment, improving the information level of health personnel, and positively affecting the behaviors of personnel. It can also be concluded that the noise observation form is reliable.

Keywords: Education, noise, health personnel, neonatal, intensive care unit

ÖZ Amaç: Gürültü özellikle preterm yenidoğanların ve sağlık çalışanlarının sağlığını olumsuz yönde etkilediği için azaltılması ve kontrol altına alınması gereken bir durumdur. Amerikan Pediatr Akademisi gürültü seviyesinin saatlik 45 dB'nin altında olması gerektiğini bildirmiştir. Ancak yapılan birçok çalışmalarda, istenilen düzeye ulaşılamadığı görülmektedir. Araștırma, yenidoğan yoğun bakım ünitesindeki gürültü düzeyini ve gürültü kontrolü için verilen eğitimin etkisini değerlendirmek amacıyla yapıldı.

Gereç ve Yöntem: Araştırma, bir hastanenin yenidoğan yoğun bakım ünitesi 3. düzeyinde çalışan doktor, hemşire ve personel üzerinde yapıldı. Tek grupta ön test-son test yarı-deneysel bir tasarım olarak yapıldı. Hastaneden etik kurul ve kurum izni alındı. Çalışmada araştırmacılar tarafından hazırlanan gürültü bilgi formu, gürültü kontrolü eğitim programı, gürültü gözlem formu ve ses ölçüm cihazı kullanıldı. Ünitede eğitim öncesi, eğitim sonrası ve eğitimden altı hafta sonra yapılan tekrarlayan ölçümde 7 gün ve 24 saat boyunca gürültü ölçümleri yapıldı.

Bulgular: Gürültü seviyesinin, eğitim öncesine kıyasla eğitimden altı hafta sonrasında anlamlı derecede düşük olduğu bulundu $(p<0,01)$. Sağlık çalışanlarının bilgi formundaki sorulara doğru cevap verme yüzdesinin de eğitimden altı hafta sonrasında eğitim öncesine kıyasla anlamlı derecede yüksek olduğu belirlendi $(p<0,01)$. Doktor, hemşire ve personelin gürültü gözlem formuna göre değerlendirilmelerinde gözlemciler arası kappa uyum düzeyinin anlamlı olduğu bulundu ( $p<0.01)$.

Sonuç: Araştırma sonucunda gürültünün azaltılmasında eğitim yönteminin etkili olduğu, ortam gürültü düzeyini azalttığı, sağlık çalışanlarının bilgi düzeyini artıırdığı ve çalışanların davranışlarını olumlu yönde etkilediği ayrıca gürültü gözlem formunun güvenilir olduğu sonucuna ulaşılabilir. Anahtar Kelimeler: Eğitim, gürültü, sağlık profesyoneli, yenidoğan, yoğun bakım ünitesi 


\section{Introduction}

Noise in neonatal intensive care units (NICU) is undesirable sound that negatively affects the health of health personnel and preterm newborns in particular (1). It is reported that in hospitals the daily volume limits should not exceed $45 \mathrm{dBA}$ during the day and $35 \mathrm{dBA}$ night (2). The American Academy of Pediatrics (AAP) recommends the hourly noise level in NICUs as $45 \mathrm{~dB}$ and below (3). In Turkey, it was reported that NICU per hour of 50-55 dB noise level should not exceed the maximum as $70 \mathrm{~dB}$ (4). Studies reported that noise levels were higher than the recommended level (5-7).

Negative effects of noise for infants in the NICU were reported with bradycardia, apnea and respiration rate, oxygen saturation, blood pressure, and sudden changes in cardiac apex beat (8). In addition, researchers reported that noise could cause hearing loss in preterm infants, and might have negative effects on language and brain development $(3,9,10)$. The World Health Organization reported that noise might have negative effects on personnel, manifesting as hearing loss, stress-related disease, sleep problems, and performance loss (11).

The sound sources in NICU are examined in two categories as functional and structural. Sounds produced by personnel and equipment constitute structural, which are the functional $(12,13)$, the sound levels of the building and the environment itself $(12,14)$. In literature (15-18) as a source of noise, sometimes human-based and some equipment sounds were placed in the first place. The noise source is the number of people working in the unit, the number and quality of equipment used, the size of the unit, etc. depending on the circumstances (16).

Many methods have been used to reduce NICU. These; the use of ear plugs (19) and ear muff (20), the use of sound-absorbing panels (21-23), the use of susceptible alarm systems $(24,25)$, the program for noise reduction, architectural configuration and training initiatives $(16,26,27)$. One such intervention is through the education of personnel in the unit. Numerous studies have demonstrated that education was effective in reducing noise $(5,16,28,29)$.

\section{Materials and Methods}

\section{Study Design, Sample and Setting}

The research was conducted in an NICU of an education and training hospital between January $1^{\text {st }}$, and March $26^{\text {th }}$,
2017, as a pre-test post-test quasi experimental design. The study population and sample comprised personnel from the unit (doctors, nurses, and personnel).

Personnel who had received no previous education on noise control and working in NICU met the selection criteria of the study.

\section{Unit Plan}

The unit consists of $1^{\text {st }}, 2^{\text {nd }}$, and $3^{\text {rd }}$ level intensive care units. The study was conducted in the $3^{\text {rd }}$ level intensive care unit. There was 1 radiant heater and 8 incubators in the unit. The distance between the incubators were planned as $120 \mathrm{~cm}$. There were mechanical ventilators, monitors, aspiratory systems, oxygen and air mixer (blender), and an infusion pump at each incubator's side. Infants in the $3^{\text {rd }}$ level NICU can be observed through a central monitor, which can record for 24 hours. Infant monitoring can be performed using phototherapy, tunnel phototherapy, transcutaneous bilirubinometry, injectomate, hypothermia devices, ultrasound, electroencephalogrphy devices, and pulse oximetry in $3^{\text {rd }}$ level NICUs. There was one sensor-fitted door that seperated the unit from other units. There was one nurse desk, two computers, one printer, three lockers with drawers in the unit, and medical waste container, four domestic waste containers, and one waste glass container near each incubator. Sanitizers and soap were sensor-fitted in the unit. Daylight was used to light the unit, and the light intensity of each incubator was adjusted with dim setting in $+/$ - directions. Twenty-six people consisting of 18 nurses, 2 assistant doctor, 1 neonatalogist, 1 associate professor, and 4 personnel worked in the unit. In 8:00 am to 4:30 pm 1 neonatalogist, 1 associate professor, 2 assistant doctor, 7 nurses, 3 personnel and 4:30 pm to 8:00 am 1 assistant doctor, 5 nurses, 2 personnel worked in NICU. The number of staff decreased to 24 after the education program because 2 nurses were appointed to another institution.

\section{Research Instruments}

Information form for personnel: Personnel' age, sex, education level, profession, and duration of work (experience) were recorded. In accordance with the literature $(5,16,28)$ an information form that was prepared by the research team ( 3 academic nurses, two clinical NICU nurses, and 1 neonatalogist) consisting of 17 multiple choice questions about sources of noise in the unit, harm of noise on infants and personnel, and practises that could be used in reducing noise levels was used. Correct answers were scored as 
1 , and incorrect answers were given 0 . The percentage of correct answers given was regarded in the evaluation.

Noise control education program: The education program included the definition of noise, factors that cause noise, instant noise levels, noise levels of units indicated in studies in the literature, effects of noise on infants and personnel, and interventions for noise reduction. The education was conducted by the researcher in the meeting room of the unit as a powerpoint presentation using a BARCOVision projector. The presentation was prepared by the research team using information in the literature $(5,16,28)$. The education was given to the doctors, nurses, and personnel in two groups on 2 consecutive days by researcher. The duration of education was 60 minutes; 45 minutes of which consisted of noise control education, and 15 minutes were allowed for questions. Notes of the education were delivered to the personnel after the education program. Two nurses who took part in the study, one as the head nurse and the other as the education nurse in NICU, were selected as educators. The educators informed personnel in the unit about interventions to be taken to reduce noise, which started from noise measurements taken after the education until the noise measurements were 6 weeks after education.

Noise measuring equipment: A Geratech Sound Level Meter DT-8852/data logger device was used for noise measurement.

Noise observation form: This form, which was prepared by the research team in accordance with the literature $(5,16,28)$ consisted of 17 practices that identified interventions to be performed by personnel in the unit to reduce noise (Table 1).

\section{Procedures}

Information form for personnel: The information form was given to doctors and nurses in face-to-face meetings just before the education program, 1 week after, and 6 weeks after the education program.

Noise measuring equipment: The device was adjusted to the range of 30-130 dB so as to provide one every second to the dBA density curve. The device was connected to a computer using a USB cable. The data were first transferred to Excel, and then to the Statistical Package for the Social Sciences (SPSS) after measurements for 24 hours. The device was purchased in November 2016 and had validity for

Table 1. Doctor, nurse, and personnel noise observation form

\begin{tabular}{|c|c|c|c|}
\hline Item & Doctor noise observation form* & Nurse noise observation form* & Personnel Noise observation form* \\
\hline 1 & $\begin{array}{l}\text { I never put anything on the incubator in } \\
\text { the unit }\end{array}$ & $\begin{array}{l}\text { I never put anything on the incubator } \\
\text { in the unit }\end{array}$ & $\begin{array}{l}\text { I never put anything on the incubator in the } \\
\text { unit }\end{array}$ \\
\hline 2 & $\begin{array}{l}\text { I speak quietly in the unit and at the } \\
\text { incubator side }\end{array}$ & $\begin{array}{l}\text { I speak quietly in the unit and at the } \\
\text { incubator side }\end{array}$ & $\begin{array}{l}\text { I speak quietly in the unit and at the } \\
\text { incubator side }\end{array}$ \\
\hline 3 & $\begin{array}{l}\text { I do not drag things in the unit and } \\
\text { corridors }\end{array}$ & $\begin{array}{l}\text { I do not drag things in the unit and } \\
\text { corridors }\end{array}$ & I do not drag things in the unit and corridors \\
\hline 4 & $\begin{array}{l}\text { I immediately respond to alarms in the } \\
\text { unit }\end{array}$ & $\begin{array}{l}\text { I immediately respond to alarms in the } \\
\text { unit }\end{array}$ & I immediately respond to alarms in the unit \\
\hline 5 & $\begin{array}{l}\text { I use my mobile phone in silent mode in } \\
\text { the unit and corridors }\end{array}$ & $\begin{array}{l}\text { I use my mobile phone in silent mode in } \\
\text { the unit and corridors }\end{array}$ & $\begin{array}{l}\text { I use my mobile phone in silent mode in the } \\
\text { unit and corridors }\end{array}$ \\
\hline 6 & $\begin{array}{l}\text { I turn down the volume of electronic } \\
\text { devices such as the telephone, radio, and } \\
\text { monitor }\end{array}$ & $\begin{array}{l}\text { I turn down the volume of electronic } \\
\text { devices such as the telephone, radio, } \\
\text { and monitor }\end{array}$ & $\begin{array}{l}\text { I turn down the volume of electronic } \\
\text { devices such as the telephone, radio, and } \\
\text { monitor }\end{array}$ \\
\hline 7 & $\begin{array}{l}\text { I do not wear noisy shoes and slippers in } \\
\text { the unit and corridors }\end{array}$ & $\begin{array}{l}\text { I do not wear noisy shoes and slippers } \\
\text { in the unit and corridors. }\end{array}$ & $\begin{array}{l}\text { I do not wear noisy shoes and slippers in the } \\
\text { unit and corridors }\end{array}$ \\
\hline 8 & I do not hit the incubator doors in the unit & $\begin{array}{l}\text { I do not hit the incubator doors in the } \\
\text { unit }\end{array}$ & I do not make noise while cleaning the unit \\
\hline 9 & - & $\begin{array}{l}\text { I remove equipment from the unit that } \\
\text { are not being used }\end{array}$ & $\begin{array}{l}\text { I remove equipment from the unit that are } \\
\text { not being used }\end{array}$ \\
\hline 10 & - & $\begin{array}{l}\text { I cover babies' ears with roller-shaped } \\
\text { cloths }\end{array}$ & $\begin{array}{l}\text { I do not shake trash bags while changing } \\
\text { them }\end{array}$ \\
\hline
\end{tabular}


a year. Noise measurements were taken for 24 hours over 7 days $B E, A E$, and 6 weeks after the education program. The device was put on the nurse desk.

Noise observation form: The observation form consisting of interventions of doctors, nurses, and personnel for reducing noise was independently evaluated by two nurses from the research group. The doctors, nurses and personnel did not know it was observed. Six weeks after education, doctors in visiting hours; nurses in care hours; and personnel in cleaning hours were observed for one day.

\section{Ethical Considerations}

Ethics board approval from the Bagcilar Training and Research Hospital Ethics Board and institutional permission from hospital management (protocol no: 2017567) were granted, and written consent was obtained from doctors, nurses and personnel.

\section{Statistical Analysis}

The Statistical Package for the IBM SPSS Statistics 22 was used in statistical analysis. The Shapiro-Wilks test was used in the evaluation of parameters with normal distribution. The ANOVA test was used in repetitive measurements and the Bonferroni test was used in the identification of time measurements that caused differences in addition to descriptive statistical methods (mean, standard deviation, frequency). Friedman's test was used in comparison of repetitive measurements with abnormal distribution, and the Mann-Whitney $U$ test was used in the determination of measuring time. Cochran's $\mathrm{Q}$ test was used in the comparison of repetitive qualitative data. Kappa compliance coefficient was used in the evaluation of compliance between the observers. Significance was regarded as $p<0.05$.

\section{Results}

Some $80.8 \%(n=21)$ of participants were female, and $19.2 \%(n=5)$ were male. The mean age was $28.81 \pm 6.58$ years, and the mean working years was $25.12 \pm 30.53$ months. Of the participants, $15.4 \%(n=4)$ were doctors, $69.2 \%(n=18)$ were nurses, and $15.4(n=4)$ were personnel; $3.8 \%(n=1)$ of personnel were primary school graduates, $7.7 \%(n=2)$ elementary school, 7.7\% ( $n=2)$ high school, $65.4 \%(n=17)$ university, and $15.4 \%(n=4)$ were masters or doctorate graduates.

The evaluation of correct answers from 17 questions on the information form revealed that the mean percentage of correct answers was $67.35 \pm 13.69 \%$ before the education program, $82.35 \pm 9.15 \%$ afterwards, and $80.88 \pm 12.35 \%$ six weeks after the education program; this difference was significant $(p<0.05)$. The mean total of correct answers increased compared with the period before the education program, and this increase was higher six weeks after education compared with the period before the program.

Table 2 shows the measurements of noise for 24 hours $B E, A E$, and RM over 7 days. Noise levels significantly decreased after education.

Table 3 demonstrates the evaluation of compliance levels of behavior scores given by the observers.

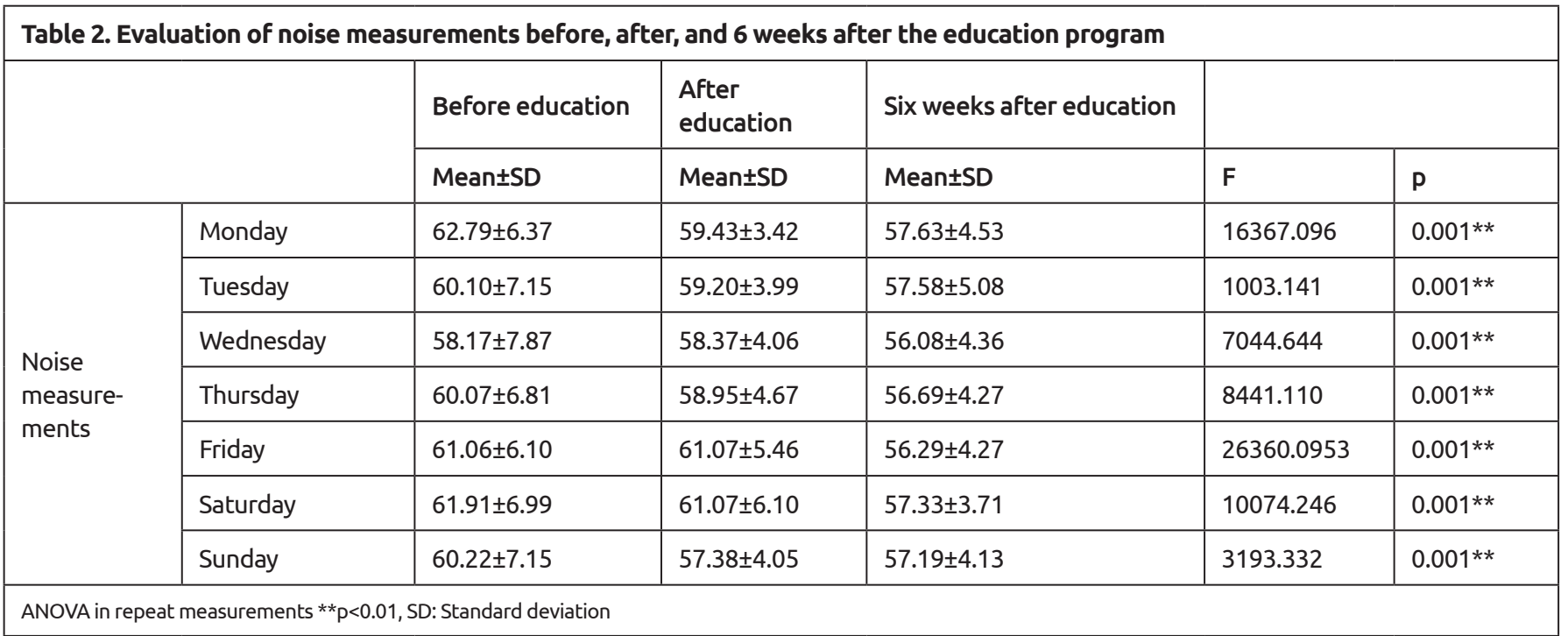




\begin{tabular}{|c|c|c|c|c|c|c|}
\hline Items & Карра & SE & Kappa & SE & Карра & SE \\
\hline 1 & $1.000 * *$ & 0.001 & 1.000 ** & 0.001 & 0.500 & 0.375 \\
\hline 2 & 0.500 & 0.375 & $0.696^{* *}$ & 0.190 & $1.000 * *$ & 0.001 \\
\hline 5 & $1.000 * *$ & 0.001 & 0.300 & 0.277 & $1.000 * *$ & 0.001 \\
\hline 6 & $1.000 * *$ & 0.001 & $1.000 * *$ & 0.001 & $1.000 * *$ & 0.001 \\
\hline 7 & $1.000 * *$ & 0.001 & 0.417 & 0.341 & $1.000 * *$ & 0.001 \\
\hline
\end{tabular}

\section{Discussion}

In a study conducted in Iran, 25 questions were prepared for NICU health personnel with the aim of reducing noise and these were asked before an education program, and 3 weeks afterwards. The level of knowledge of health personnel was found significantly higher $A E(83.4 \pm 9.5)$ compared with $B E$ (74.6 \pm 8.2 ) (28). The present study revealed that the level of knowledge of health personnel was significantly higher $A E$ and RM. The education program seemed to increase the level of knowledge of personnel. However, repeated education may be effective in making the information permanent. In the present study, although the percentage of correct answers given was higher 6 weeks after education compared with $\mathrm{BE}$, the percentage was lower than the AE period. This result shows that education is required to be repeated.

In a study in India, a noise reduction protocol was established to reduce noise. Within this protocol, there was a change of behavior (such as informing all personnel about the harmful effects of noise in infants, avoid shouting across a distance, to speak in low tones, shutting down radios, alerting loud speakers, putting silent reminders in the unit and in corridors) environmental changes (such as wearing rubber feet on the legs of the items, replacing metal items with plastic ones, reducing the alarms of the devices, keeping the doors closed, phones at minimum volume). As a result of the study, $9.58 \mathrm{~dB}$ in the ventilation room, 6.54 $\mathrm{dB}$ in the normal room, $2.26 \mathrm{~dB}$ in the isolation room, 2.09 $\mathrm{dB}$ in the extreme preterm room and $2.37 \mathrm{~dB}$ were achieved
(26). In a study conducted in the United States, training of healthcare professionals, talking softly, be placed on the bare incubator material for use in silent alarm mode of the device during maintenance, doors, trash and so on. opening and closing means of the sensor quiet operation, by replacing the plastic metals, quiet time periods set a result of the noise level around the incubator $(p=0.01)$ and healthcare professionals work areas $(p=0.001)$ decrease was observed (30). In a study conducted in Canada, noise measurements during 1 month (pre-intervention) training protocol after the noise measurements for 2 months with alarm system the health personnel and the family was made two months measured by visual stimuli. The weekends were determined to have a quieter environment $(p<0.001)$ and a decrease in noise level ( $p=0.01$ ) compared to the weekdays (27). In the present study, a significant decrease was detected in the unit in RM with the use of education in addition to normal education (2.09-5.16 dBA). Researchers reported that a $3 \mathrm{~dB}$ decrease was equivalent to a $50 \%$ change in noise levels because the decibel is a logarithmic unit (27). Twenty-fourhour noise measurements, both $\mathrm{BE}$ and $\mathrm{AE}$, on Monday, Friday, and Sunday were compared in a study, and about a $3 \mathrm{~dB}$ decrease was detected using the education method (16). A significant decrease in noise levels in RM in the present study showed that education had a positive effect, and supporting normal education might have a significant role in behavior change, and in reducing noise levels. The present study and other studies $(1,16,17)$ revealed that noise 
levels measured for 24 hours were higher than the AAP's recommendations (Table 2). Therefore, interventions for reducing noise must be applied effectively. It was observed that noise levels significantly decreased 6 weeks after the education program compared with $\mathrm{BE}$. This shows that education contributes to behavior changes in personnel.

Behaviors of health personnel were observed and recorded by the observers. Some behaviors were evaluated the same by both observers at the end of the two observations, and compliance levels were significant. Both observers evaluated items $1,3,4,5,6$, and 7 as the same; however, they evaluated items 2 and 8 as different. The observers noted that doctors did not behave the same in practices such as "speaking in low voice" and "banging incubator doors" (Table 3). Items 1, 2, 4, 6, 8 , 9, and 10 were evaluated as the same for nurse group, items 3,5 , and 7 were evaluated as different. Neither observer observed the same for nurses in practices such as "not dragging things," "using mobile phones in silent mode," and "not wearing slippers and shoes that make noise (Table 3). In the personnel group, items $2,5,6,7$, and 9 were evaluated as in compliance; however, items 1, 3, 4, 8, and 10 were different. Accordingly, personnel did not behave the same in practices such as "not putting anything on the incubators in the unit," "not dragging things in the unit and corridors," "immediately responding to alarm sounds in the unit," "not making noise while cleaning the unit," and "not shaking trash bags while changing" them (Table 3). In conclusion, the compliance evaluation between observers related to observation form was generally significant. Although some behaviors changed in health personnel, some behaviors remained the same. To make behaviors permanent in reducing noise, repeated education programs and continuation of observations are required. Therefore, efforts to create awareness must be continued.

\section{Study Limitations}

The research is valid for the unit where the study was conducted. No separate education was prepared for the families. Content validity was not done for the forms used in the research.

\section{Conclusion}

In conclusion, the education method was effective in reducing noise, reducing noise in the environment, increasing the knowledge level of health personnel, and positively affected personnel' behaviors. Furthermore, frequent repetition of training is crucial in controlling noise and creating behavioral changes. In addition, the noise observation form was reliable. We recommend that noise observation forms should be used as a likert-type scales in further research.

\section{Ethics}

Ethics Committee Approval: Ethics board approval from the Bagcilar Training and Research Hospital ethics board (protocol no: 2017567) and institutional permission from hospital management were granted.

Informed Consent: Written consent was obtained from doctors, nurses and personnel.

Peer-review: Externally peer-reviewed.

\section{Authorship Contributions}

Design: M.Ç.I., S.B., B.M., Data Collection or Processing: M.Ç.I., E.Ç., N.U.Ö., Analysis or Interpretation: M.Ç.I., Literature Search: M.Ç.I., S.B., B.M., S..H.

Conflict of Interest: No conflict of interest was declared by the authors.

Financial Disclosure: The authors declared that this study received no financial support. 


\section{References}

1. Carvalhais C, Santos J, da Silva MV, Xavier A. Is There Sufficient Training of Health Care Staff on Noise Reduction in Neonatal Intensive Care Units? a Pilot Study From Neonoise Project. J Toxicol Environ Health A. 2015:78:897-903.

2. EPA. Noise effects handbook: Adesk reference to health and welfare effects of noise. http://www.nonoise.org/ library/handbook/handbook.htm (Erişim: 18.07.2018).

3. Noise: a hazard for the fetus and newborn. American Academy of Pediatrics. Committee on Environmental Health. Pediatrics. 1997;100:724-7.

4. Yataklı Sağlık Tesislerinde Yoğun Bakım Hizmetlerinin Uygulama Usul Ve Esasları Hakkında Tebliğde Değişiklik Yapılmasına Dair Tebliğ. http://www.resmigazete. gov.tr/eskiler/2011/07/20110720-15.htm (Erişim: 18.07.2018).

5. Hassanein SN, El Raggal NM, Shalaby AA. Neonatal nursery noise: practice-based learning and improvement. J Matern Fetal Neonatal Med. 2013;26:392-5.

6. Neille J, George K, Khoza-Shangase K. A study investigating sound sources and noise levels in neonatal intensive care units. South African Journal of Child Health 2014;8:6-10.

7. Olivera JM, Rocha LA, Ruiz E, Rotger VI, Herrera MC. New Approach to evaluate acoustic pollution in hospital environments. Journal of Physics: Conference Series 2013:477:1-10.

8. Wachman EM, Lahav A. The effects of noise on preterm infants in the NICU. Arch Dis Child Fetal Neonatal Ed. 2011;96:F305-9.

9. Brown G. NICU noise and the preterm infant. Neonatal Netw. 2009;28:165-73.

10. Surenthiran SS, Wilbraham K, May J, Chant T, Emmerson AJB, Newton, VE. Noise levels within the ear and postnasal space in neonates in intensive care. Arch Dis Child Fetal Neonatal Ed. 2003;88:F315-8.

11. World Health Organisation (WHO). Burden of disease from environmental noise:
Quantification of healthy life years lost in Europe. The Regional Office for Europe. 2011, Denmark. http://www.euro.who. int/_data/assets/pdf_file/0008/136466/ e94888.pdf

12. Topf M. Hospital noise pollution: an environmental stress model to guide research and clinical interventions. Adv Nurs. 200;31:520-8.

13. Johnson AN. Adapting the neonatal intensive care environment to decrease noise. J Perinat Neonatal Nurs. 2003;17:280-8.

14. Philbin MK. Planning the acoustic environment of a neonatal intensive care unit. Clin Perinatol. 2004;31:331-52.

15. Nathan LM, Tuomi SK, Müller AM, Kirsten GF. Noise levels in a neonatal intensive care unit in the Cape Metropole. South African Journal of Child Health 2008;2:504.

16. Calikusu Incekar M, Balci S. The effect of training on noise reduction in neonatal intensive care units. J Spec Pediatr Nurs. 2017;22.

17. Valizadeh $S$, Hosseini MB, Alavi $\mathrm{N}$, Asadollahi M, Kashefimehr S. Assessment of sound levels in a neonatal intensive care unit in tabriz, Iran. J Caring Sci. 2013;2:19-26.

18. Weich TM, Ourique AC, Tochetto TM, Franceschi CM. Effectiveness of a noise control program in a neonatal intensive care unit. Rev Bras Ter Intensiva. 2011:23:327-34.

19. Abou Turk C, Williams AL, Lasky RE. A randomized clinical trial evaluating silicone earplugs for very low birth weight newborns in intensive care. J Perinatol. 2009;29:358-63.

20. Duran R, Ciftdemir NA, Ozbek UV, Berberoğlu U, Durankuş F, Süt N. et al. The effects of noise reduction by earmuffs on the physiologic and behavioral responses in very low birth weight preterm infants. nt J Pediatr Otorhinolaryngol. 2012;76:14903.

21. Johnson AN. Neonatal response to control of noise inside the incubator. Pediatr Nurs. 2001;27:600-5
22. Altuncu $E$, Akman I, Külekci $S$, Akdas $F$ Bilgen $\mathrm{H}$, Ozek E. Noise levels in neonatal intensive care unit and use of sound absorbing panel in the isolette. nt J Pediatr Otorhinolaryngol. 2009;73:951-3.

23. Kellam B, Bhatia J. Effectiveness of an acoustical product in reducing highfrequency sound within unoccupied incubators. J Pediatr Nurs. 2009;24:33843.

24. Jousselme C, Vialet R, Jouve E, Lagier P, Martin C, Michel F. Efficacy and mode of action of a noise-sensor light alarm to decrease noise in the pediatric intensive care unit: a prospective, randomized study. Pediatr Crit Care Med. 2011 Mar;12:e69-72.

25. Wang D, Aubertin C, Barrowman N, Moreau K, Dunn S, Harrold J. Reduction of noise in the neonatal intensive care unit using sound-activated noise meters. Arch Dis Child Fetal Neonatal Ed. 2014;99:F515-6.

26. Ramesh A, Suman Rao PN, Sandeep G, Nagapoornima M, Srilakshmi V, Swarnarekha M. Efficacy of a low cost protocol in reducing noise levels in the neonatal intensive care unit. Indian J Pediatr. 2009;76:475-8.

27. Wang D, Aubertin C, Barrowman N, Moreau K, Dunn S, Harrold J. Examining the effects of a targeted noise reduction program in a neonatal intensive care unit. Arch Dis Child Fetal Neonatal Ed. 2014;99:F203-8.

28. Biabanakigoortani A, Namnabati $M$, Abdeyazdan Z, Badii Z. Effect of peer education on the noise management in Iranian neonatal intensive care unit. Iran J Nurs Midwifery Res. 2016;21:317-21.

29. Yıldırım Ar A, Turan G, Alay EE, Demiroluk Ö, Kuplay YY, Karaca D. Yoğun Bakımda Gürültü Farkındalığı lçin Neler Yapabiliriz? Turkish Journal of Intensive Care 2018;16:10-16.

30. Liu WF; NIC/Q 2005 Physical Environment Exploratory Group. The impact of a noise reduction quality improvement project upon sound levels in the open-unit-design neonatal intensive care unit. J Perinatol. 2010;30:489-96. 